Article

\title{
Antioxidant and Anti-Obesity Potentials of Korean-Native Wild Vegetables (Allium species)
}

\author{
Ji Yeon Lee ${ }^{1,+}{ }^{+}$, Kyung Hye Seo ${ }^{2,+}$, Eun Young Lee ${ }^{3,+}$, Yun-Jeong Ji ${ }^{3}{ }^{-}$, Yun Ji Lee ${ }^{3}$, Min Hye Kang ${ }^{3}$, \\ Hyun-A Seong ${ }^{4}$ and Hyung Don Kim ${ }^{3,4, * \mathbb{D}}$
}

1 MEDIOGEN, Co., Ltd., Jecheon 27159, Korea; wldus8964@gmail.com

2 Development of Horticultural Crop Research, National Institute of Horticultural \& Herbal Science, RDA, Jeonju 55365, Korea; seokh@korea.kr

3 Department of Herbal Crop Research, National Institute of Horticultural \& Herbal Science, RDA, Eumsung 27709, Korea; ley0409@korea.kr (E.Y.L.); jyj2842@korea.kr (Y.-J.J.); yoong0625@korea.kr (Y.J.L.); mohak2@korea.kr (M.H.K.)

4 Department of Biochemistry, School of Life Sciences, Chungbuk National University, Cheongju 28644, Korea; haseung@cbnu.ac.kr

* Correspondence: khd0303@rda.go.kr

+ These authors contributed equally to this work.

\section{check for} updates

Citation: Lee, J.Y.; Seo, K.H.; Lee, E.Y.; Ji, Y.-J.; Lee, Y.J.; Kang, M.H.; Seong, H.-A.; Kim, H.D. Antioxidant and Anti-Obesity Potentials of Korean-Native Wild Vegetables (Allium species). Horticulturae 2021, 7, 541. https://doi.org/10.3390/ horticulturae7120541

\section{Academic Editors:}

Jelena Popović-Djordjević and Luiz Fernando Cappa de Oliveira

Received: 2 November 2021

Accepted: 29 November 2021

Published: 2 December 2021

Publisher's Note: MDPI stays neutral with regard to jurisdictional claims in published maps and institutional affiliations.

Copyright: (c) 2021 by the authors. Licensee MDPI, Basel, Switzerland. This article is an open access article distributed under the terms and conditions of the Creative Commons Attribution (CC BY) license (https:/ / creativecommons.org/licenses/by/ $4.0 /)$.

\begin{abstract}
Four Korea-native wild vegetables belonging to the Allium genus (Allium tuberosum Rottl., Allium senescens L., Allium thunbergii G. Don., and Allium sacculiferum Maxim.) were investigated for their antioxidant and anti-obesity potential, in order to promote the utilization of wild edible plants for the development of potential new crops. In this study, we compared the antioxidant activity of the plant extracts by ABTS+ and DPPH scavenging method. We then compared the anti-adipogenic effects of the extracts in adipocytes. We quantified the phenolics in the extracts using high-performance liquid chromatography (HPLC) to identify the bioactive compounds. A. tuberosum and $A$. sacculiferum had a higher total phenolic content $(19.0 \pm 0.3$ and $19.6 \pm 0.7 \mathrm{mg} \mathrm{GA} / \mathrm{g}$ extract, respectively) than $A$. senescens and $A$. thunbergii (16.0 \pm 0.2 and $14.5 \pm 0.7 \mathrm{mg} \mathrm{GA} / \mathrm{g}$ extract). Caffeic acid, an antioxidant and anti-adipogenic compound, was detected in A. tuberosum and A. sacculiferum, but not in $A$. senescens and $A$. thunbergii. A. tuberosum, and $A$. sacculiferum showed superior antioxidative and anti-adipogenic activities compared to $A$. senescens and $A$. thunbergii. Therefore, $A$. tuberosum and $A$. sacculiferum, both of which contain antioxidant and anti-adipogenic phenolics, such as caffeic acid, present a therapeutic potential against obesity. Various phenolic compounds, which have been found to differ among Allium spp., may partially account for differences among the Allium spp. with respect to their antioxidant and anti-obesity effects.
\end{abstract}

Keywords: Allium tuberosum Rottl; Allium senescens L.; Allium thunbergii G. Don.; Allium sacculiferum Maxim.; wild vegetable; phenolic; antioxidant; antiobesity

\section{Introduction}

Globally, obesity has emerged as a major cause of various metabolic diseases, such as diabetes, cardiovascular disease, and osteoporosis. It is known that high-fat or highcalorie diets can cause hyperlipidemia, obesity, increased oxidative stress, and increased inflammation [1]. Oxidative stress disrupts the balance between reactive oxygen species (ROS) and antioxidant defense systems [2]. Oxidative stress causes cellular DNA damage and the oxidation of enzyme cofactors, thus resulting in various diseases such as cancer, neurodegenerative diseases, and aging processes [3]. In addition, oxidative stress promotes adipogenesis through NADPH oxidase, a major source of intracellular lipid and ROS generation [4]. Oxidative stress, including free radicals and ROS, can be inhibited or eliminated by enzymatic and non-enzymatic antioxidants to maintain cell balance [5]. According to recent studies, maintaining hypoglycemia, regulating the body's antioxidant 
system and insulin, inhibiting the differentiation and proliferation of pre-adipocytes, and suppressing adipogenesis are all thought to suppress obesity [6].

Plants generate specialized metabolites in order to protect themselves against insects, viruses, and dispersing animals $[7,8]$. These metabolites include alkaloids, glycosides, amines, steroids, flavonoids, and related metabolites $[7,8]$. They possess biological activities and are mostly found in the leaves of various plants [7]. Among plant metabolites, phenolics have various biological effects, such as antioxidant, anti-microbial, and anti-diabetic properties [9]. In particular, phenolics are compounds directly linked to non-enzymatic antioxidants because of their reactivity as hydrogen or electron donors and reactivity with other antioxidants [10]. Phenolics are useful natural compounds capable of preventing oxidative stress and are considered important in food, pharmaceutical, and cosmetic industries [11].

Wild vegetables and flowers of the Allium spp. belong to the Amaryllidaceae family, with approximately 977 different spp. of garlic, onions, chives, shallots, and leeks [12]. The most important Allium spp. contain flavonoids, organosulfur compounds, and saponin. Allium tuberosum (A. tuberosum) grows in the wild in the central and northern parts of Asia, such as Japan, China, Korea, India, Nepal, Thailand, and the Philippines. Of these countries, only China, Korea, and Japan use A. tuberosum as a food source [12]. In Korea, A. tuberosum grows in the mountains, and its industrial cultivation has increased due to the development of greenhouses, pest control technology, and pharmaceuticals. A. tuberosum is a greenyellow vegetable that contains many nutrients, such as carotene, vitamin B2, vitamin $C$, calcium, and iron. It is known to have anti-cancer [13], anti-bacterial [14], anti-diabetic, hepatoprotective [15], and anti-obesity activities [16]. Other Allium spp. that are cultivated in Korea include A. anisopodium, A. cyanem, A. cyanem var. deltoides, A. deltoidefistulosum, A. senescens, A. thunbergii, and A. sacculiferum. [12]. Of these, A. senescens, A. thunbergii, and $A$. sacculiferum have anti-obesity, anti-cancer, and anti-inflammatory activities [16-19]. Although the classification and growth among Allium spp. in Korea are being studied, studies on their biological activity and phenolic profiling are scarce [20,21].

In this study, we analyzed the general growth characteristics of four Allium spp. (A. tuberosum, A. senescens, A. thunbergii, and A. sacculiferum) in identical environmental conditions and determined their antioxidant and anti-adipogenic activities. We also investigated their bioactive components by total phenol (TP) content analysis and phenolic profiling.

\section{Materials and Methods}

\subsection{Plant Material and Growth Characteristics}

The plant samples of Allium spp. (A. tuberosum, A. senescens, A. thunbergii, and A. sacculiferum) were collected from Korea. Voucher specimens were deposited at the Korea Medicinal Resources Herbarium, Eumseong, Korea (Table 1).

Table 1. Collection sites, voucher numbers, local names, and parts used of Allium spp.

\begin{tabular}{|c|c|c|c|c|}
\hline Plant & Collection Site & Voucher No. & Local Names & Parts Used \\
\hline A. tuberosum & $\begin{array}{c}\text { Mt.Obong, } \\
\text { (Yangyang, Gangwon) }\end{array}$ & MPS001706 & Buchu & Aerial part \\
\hline A. senescens & $\begin{array}{c}\text { Peak. Hyangro, } \\
\text { (Yangyang, Gangwon) }\end{array}$ & MPS005298 & Dume-buchu & Aerial part \\
\hline A. thunbergii & $\begin{array}{c}\text { Mt.Sobaek, } \\
\text { (Danyang, Chungbuk) }\end{array}$ & MPS004662 & San-buchu & Aerial part \\
\hline A. sacculiferum & $\begin{array}{c}\text { NIHHS } \\
\text { (Eumseong, Chungbuk) }\end{array}$ & MPS005491 & Chamsan-buchu & Aerial part \\
\hline
\end{tabular}

Allium spp. seeds were sown in 200-cell plug trays $(60 \mathrm{~cm} \times 41 \mathrm{~cm} \times 5 \mathrm{~cm})$ containing commercial medium (Baroker medium, SeoulBio, Eumseong, Korea) and were maintained at $20 \pm 5{ }^{\circ} \mathrm{C}$ in a greenhouse. After 15 days, the seedlings were cultivated in the field. 
Allium spp. were harvested after 2 months (15 June 2018), and their growth characteristics were examined (Figure 1). For subsequent experiments, $50 \mathrm{~g}$ of Allium spp. was extracted with water $(500 \mathrm{~mL})$, repeated 3 times, at room temperature for $24 \mathrm{~h}$ and concentrated using an evaporator system under reflux (BÜCHI, Meierseggstrasse, Flawil, Switzerland). Allium spp. extracts were freeze-dried.

\subsection{Cell Culture}

The 3T3-L1 pre-adipocytes were purchased from the American Type Culture Collection (CL-173, ATCC, Manassas, VA, USA). 3T3-L1 preadipocytes were cultured in Dulbecco's modified Eagle's medium (DMEM, Gibco, Mississauga, Canada) containing $1 \times$ penicillin/streptomycin/glutamine (PSG, Gibco, Mississauga, Canada) and 10\% bovine calf serum (Gibco, Mississauga, Canada) at $37{ }^{\circ} \mathrm{C}$ in a $5 \% \mathrm{CO}_{2}$ incubator. The medium was replaced every 2 days for subculture. Cells were used at passages 5-10 in all of the experiments.

\subsection{Cell Viability}

Cell viability was measured with CellTiter $96^{\circledR}$ AQueous One Solution according to the manufacturer's instructions (Promega, Madison, WI, USA) [22]. The 3T3-L1 pre-adipocytes were cultured in 96-well plates at $1 \times 10^{5}$ cells $/ \mathrm{mL}$ for $24 \mathrm{~h}$ and were treated with Allium spp. extracts. After $24 \mathrm{~h}$, the absorbance was measured at $490 \mathrm{~nm}$ using a multi-plate reader (Synergy H1, Biotek, Winooski, VT, USA).

\subsection{Differentiation of Pre-Adipocytes}

The 3T3-L1 preadipocytes were differentiated as previously described [23]. Briefly, confluent pre-adipocytes were differentiated using DMEM containing $10 \%$ fetal bovine serum (FBS, Gibco, Mississauga, Canada), $1 \times$ PSG, $1 \mathrm{mM}$ insulin (Gibco, Mississauga, Canada), $0.5 \mathrm{mM}$ isobutylmethylxanthine (Sigma-Aldrich, St. Louis, MO, USA), and dexamethasone $(0.1 \mathrm{mM})$ (Sigma-Aldrich, St. Louis, MO, USA) for 3 days. DMEM media with $10 \%$ FBS, $1 \times$ PSG and $1 \mathrm{mM}$ insulin was used until cells were completely differentiated for an additional 6 days.

\subsection{ORO Staining}

Cultures were fixed for at least $1 \mathrm{~h}$ with $10 \%$ formalin diluted in water, in a $37^{\circ} \mathrm{C}$ incubator, then washed twice with water and stained with a working solution of ORO (Sigma-Aldrich, St. Louis, MO, USA). To determine the extent of adipose conversion, 100\% isopropanol was added to the stained tissue [24]. The absorbance of the extracted dye was read at $510 \mathrm{~nm}$ using a microplate reader.

\subsection{Phenolic Analysis and Antioxidant Activity}

\subsubsection{DPPH Free Radical Scavenging Assay}

The antioxidant activity of Allium spp. was determined using a DPPH (2,2-diphenyl1-picrylhydrazyl; Sigma-Aldrich, St. Louis, MO, USA) scavenging assay following the method of Nazlić with some modifications. Briefly, $40 \mu \mathrm{L}$ of sample $(0.05,0.1,0.2,0.5,1$, and $2 \mathrm{mg} / \mathrm{mL})$ was mixed with $0.2 \mathrm{mM} \mathrm{DPPH}(160 \mu \mathrm{L})$ [25]. After $30 \mathrm{~min}$, the absorbance was measured at $517 \mathrm{~nm}$ using a multimode microplate reader. The DPPH radical scavenging activity was expressed as $\mathrm{IC}_{50}$ value, a concentration that scavenges $50 \%$ of the free radicals.

\subsubsection{ABTS Radical Scavenging Assay}

The $\mathrm{ABTS}^{+}$scavenging assay was performed as described by Tanruean et al., with slight modifications [26]. The $\mathrm{ABTS}^{+}$solution was prepared with ABTS tablets (SigmaAldrich, St. Louis, MO, USA) and potassium persulfate $(2.6 \mathrm{mM})$ at $4{ }^{\circ} \mathrm{C}$ for $16 \mathrm{~h}$ with the light blocked. Absorbance was measured at $734 \mathrm{~nm}$ using a multi-mode microplate reader. The radical scavenging activity was expressed as $\mathrm{IC}_{50}$ value, a concentration that scavenges $50 \%$ of the radicals. 


\subsubsection{Determination of TP Content}

The TP content was analyzed using the Folin-Denis method [27]. Briefly, $500 \mu \mathrm{L}$ of each extract $(3 \mathrm{mg} / \mathrm{mL}$ ) was added to $50 \mu \mathrm{L}$ of Folin-Ciocalteu reagent (Sigma-Aldrich, $\mathrm{MO}$, USA). After $5 \mathrm{~min}, 100 \mu \mathrm{L}$ of $20 \%$ sodium carbonate anhydrous saturated solution was added. After $1 \mathrm{~h}$, the absorbance was measured at $725 \mathrm{~nm}$ using a multi-plate reader. The TP content was determined through a comparison with the standards. Gallic acid (Sigma-Aldrich, USA) was used as a standard, and the TP content $(\mathrm{mg} / \mathrm{g}$ ) was determined using the following equation $\left(R^{2}=0.999\right)$ :

$$
\mathrm{Y}=0.0058 \mathrm{X}-0.0165
$$

where $\mathrm{Y}$ is absorbance and $\mathrm{X}$ is measured concentration $(\mathrm{mg} / \mathrm{mL})$.

\subsubsection{Phenolics Analysis Using HPLC}

The Agilent 1200 series HPLC was used (Agilent Technologies, Santa Clara, CA, USA) and samples were analyzed through a reversed-phase using a synergy fusion RP column $(250 \times 4.6 \mathrm{~mm}, 4 \mu \mathrm{m}$; Phenomenex, Torrance, CA, USA). All analysis conditions were performed as previously described [28]. Phenolic standards such as homogentisic acid, protocatechuic acid, gentisic acid, chlorogenic acid, caffeic acid, phloretic acid, p-coumaric acid, ferulic acid, veratric acid, cinnamic acid, quercetin, and naringenin (Sigma-Aldrich, St. Louis, MO, USA) were prepared and filtered using $0.45 \mu \mathrm{M}$ polyvinylidene difluoride (PVDF; Pall Co., Port Washington, NY, USA).

\subsection{Statistical Analysis}

All experimental results are presented as the mean \pm standard deviation (SD) of three independent experiments. The statistical significance of the differences was calculated using a one-way analysis of variance (ANOVA) using Duncan's test, and correlations were calculated using Pearson's correlation coefficient (Statistical Package for the Social Sciences, ver. 21.0 for Window).

\section{Results}

\subsection{Growth Characteristic of Allium Spp.}

In this study, the growth characteristics of four Allium spp. (A. tuberosum, A. senescens, A. thunbergia, and A. sacculiferum) were measured immediately after cultivation (Figure 1 and Table 2). The total length was similar among the Allium spp., at 212-244 mm, except for A. sacculiferum, which was $110.8 \mathrm{~mm}$ in length. The stem diameter and root length differed considerably between $A$. tuberosum and $A$. sacculiferum, but the number of leaves did not show a significant difference among species.

Table 2. Plant height, stem diameter, length of root, and number of leaves according to Allium spp.

\begin{tabular}{ccccc}
\hline Plant & $\begin{array}{c}\text { Plant Height } \\
\mathbf{( M m )}\end{array}$ & $\begin{array}{c}\text { Stem Diameter } \\
\mathbf{( M m})\end{array}$ & $\begin{array}{c}\text { Length of Longest } \\
\text { Root } \mathbf{( M m})\end{array}$ & $\begin{array}{c}\text { Number of } \\
\text { Leaves }\end{array}$ \\
\hline A. tuberosum & $212.5 \pm 4.3^{\mathrm{b}}$ & $0.4 \pm 0.0^{\mathrm{c}}$ & $78.7 \pm 3.5^{\mathrm{b}}$ & $4.0 \pm 1.4^{\mathrm{a}}$ \\
A. senescens & $242.0 \pm 9.5^{\mathrm{a}}$ & $46.7 \pm 2.9^{\mathrm{a}}$ & $114.8 \pm 10.9^{\mathrm{a}}$ & $3.7 \pm 0.6^{\mathrm{ab}}$ \\
A. thunbergii & $244.5 \pm 11.0^{\mathrm{a}}$ & $35.0 \pm 10.6^{\mathrm{b}}$ & $124.0 \pm 17.7^{\mathrm{a}}$ & $2.3 \pm 0.0^{\mathrm{b}}$ \\
A. sacculiferum & $110.8 \pm 18.7^{\mathrm{c}}$ & $2.0 \pm 0.7^{\mathrm{c}}$ & $40.0 \pm 4.2^{\mathrm{c}}$ & $3.3 \pm 0.0^{\mathrm{ab}}$ \\
\hline
\end{tabular}

All values are means \pm SD, and values with different superscript letters on the same column indicate a statistically significant difference determined by Duncan's test $(p<0.05)$. 


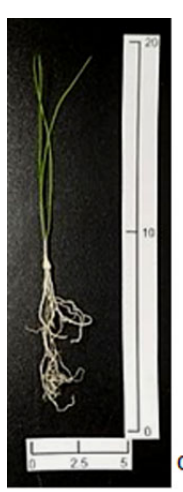

(a)

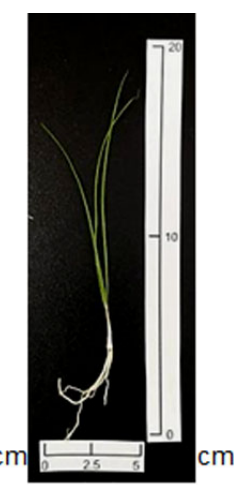

(b)

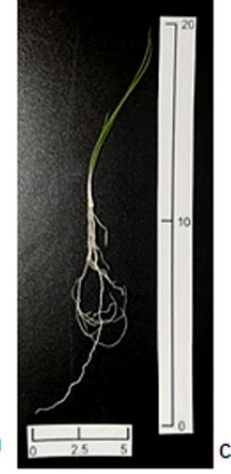

(c)

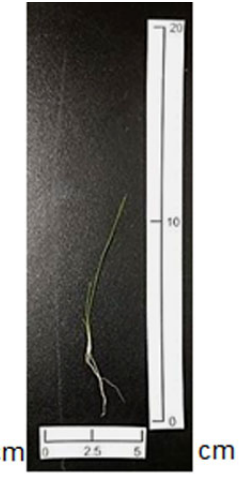

(d)

Figure 1. General images of A. tuberosum (a), A. senescens (b), A. thunbergii (c), and A. sacculiferum (d).

\subsection{Antioxidant Activities of Allium Spp.}

The antioxidant activity of Allium spp. were evaluated using DPPH and ABTS free radical scavenging methods, which are common and rapid methods for in vitro antioxidant assay [29]. The $\mathrm{IC}_{50}$ values of Allium spp. for DPPH and ABTS + scavenging activity varied from 694.2 to 980.0 and from 44.0 to $396.2 \mu \mathrm{g} / \mathrm{mL}$, respectively (Table 3). The extracts of A. tuberosum $(694.2 \pm 10.0 \mu \mathrm{g} / \mathrm{mL})$ and A. sacculiferum $(723.1 \pm 12.3 \mu \mathrm{g} / \mathrm{mL})$ showed higher scavenging activity for DPPH free radical without significant differences between them. The extract of $A$. sacculiferum showed the highest ABTS ${ }^{+}$scavenging $(44.0 \pm 0.7 \mu \mathrm{g} / \mathrm{mL})$. The highest yield of Allium spp. was approximately $55 \%$ and was consistent with all spp. except for $A$. tuberosum.

Table 3. Anti-oxidative activities of Allium spp. water extracts.

\begin{tabular}{ccccc}
\hline \multirow{2}{*}{ Plants } & \multicolumn{2}{c}{ Antioxidant Activity ${ }^{\mathbf{1}}$} & \multirow{2}{*}{ TP $^{\mathbf{2}}$} & \multirow{2}{*}{ Yields $^{\mathbf{3}}$} \\
\cline { 2 - 3 } & Dpph & Abts $^{+}$ & & \\
\hline A. tuberosum & $694.2 \pm 10.7^{\mathrm{b}}$ & $100.2 \pm 1.7^{\mathrm{b}}$ & $17.6 \pm 0.3^{\mathrm{a}}$ & 29.7 \\
A. senescens & $880.0 \pm 51.4^{\mathrm{a}}$ & $101.1 \pm 3.7^{\mathrm{b}}$ & $16.0 \pm 0.2^{\mathrm{c}}$ & 55.3 \\
A. thunbergii $^{\mathrm{a}}$ & $980.0 \pm 5.1^{\mathrm{a}}$ & $396.2 \pm 2.6^{\mathrm{a}}$ & $14.5 \pm 0.7^{\mathrm{d}}$ & 55 \\
A. sacculiferum & $723.1 \pm 12.3^{\mathrm{c}}$ & $44.0 \pm 0.7^{\mathrm{c}}$ & $17.3 \pm 0.1^{\mathrm{b}}$ & 53.1 \\
Ascorbic acid & $55.34 \pm 2.08^{\mathrm{d}}$ & $31.29 \pm 1.47^{\mathrm{d}}$ & - & - \\
\hline
\end{tabular}

${ }^{1}$ Values are indicated as $\mathrm{IC}_{50}$ values $(\mu \mathrm{g} / \mathrm{mL}) .{ }^{2}$ Total phenolic acid (mg GA/g extract). ${ }^{3}$ Extract yield (\%). All values are means $\pm S D$, and values with different superscript letters on the same column indicate a statistically significant difference determined by Duncan's test $(p<0.05)$.

\subsection{Cell Viability of Allium Spp.}

The viability of 3T3-L1 cells, when treated with the Allium spp. Extract, was investigated using the MTS assay, which is commonly used for cell viability analyses by measuring the activity of mitochondrial dehydrogenase (Figure 2) [30]. There was no difference observed in the viability of 3T3-L1 cells when treated with $25-200 \mu \mathrm{g} / \mathrm{mL}(\geq 100 \%)$ of Allium spp. extract. It has been reported that cells are considered highly viable if the viability is more than $90 \%$ [31]. Thus, extracts of Allium spp. of concentrations up to $100 \mu \mathrm{g} / \mathrm{mL}$ $(\geq 90 \%)$ were chosen for subsequent experiments. 

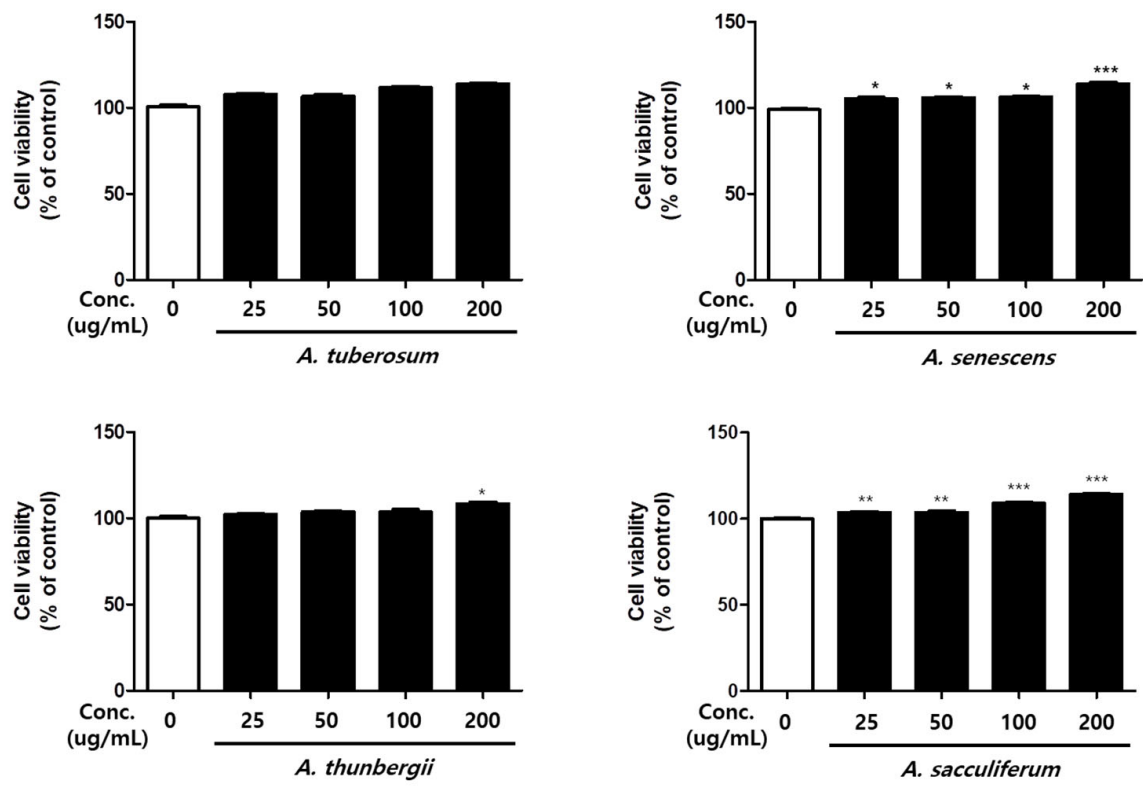

Figure 2. Effect of Allium spp. extracts (25-200 $\mu \mathrm{g} / \mathrm{mL}$ ) on viability of 3T3-L1 cell, analyzed by MTS assay. All values are means $\pm \mathrm{SD}(n=3)$. The statistically significant difference was determined by Duncan's test ${ }^{*} p<0.05,{ }^{* *} p<0.01$ and $\left.{ }^{* * *} p<0.001\right)$. Conc., concentration.

\subsection{Effect of The Differentiation Inhibition of Allium Spp. by ORO Staining}

Adipogenesis has been reported to contribute to the differentiation of pre-adipocytes into adipocytes, lipid accumulation, and growth arrest [32]. Lipid droplet accumulation in adipocytes is known to be an indicator of adipogenesis [33]. Therefore, the anti-adipogenic effect of Allium spp. extracts, with a media of differentiation (MDI), were evaluated using ORO in 3T3-L1 cells (Figure 3A). Microscopy revealed that the MDI positive control had more stained lipid droplets than in the undifferentiated negative controls. The amount was also significantly increased in the differentiated controls, to 2.01-fold higher than the undifferentiated control. Cells treated with extracts of A. tuberosum (50 and $100 \mu \mathrm{g} / \mathrm{mL}$; 0.82 and 0.74 -fold vs. MDI control, $p<0.05$ ) and A. sacculiferum (50 and $100 \mu \mathrm{g} / \mathrm{mL} ; 0.69$ and 0.57 -fold vs. MDI control, $p<0.05$ ) had markedly decreased lipid droplets, as shown in Figure 3B.

A

MDI

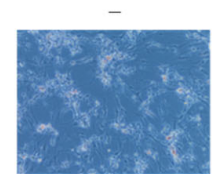

$+$

100

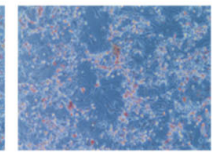

A. tuberosum

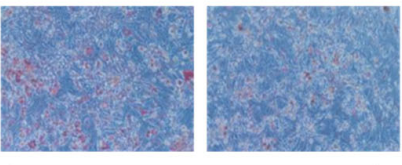

A. thunbergil
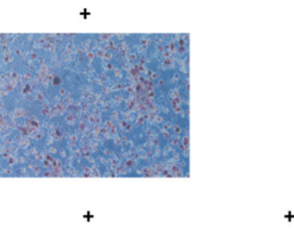

$50 \quad 100$

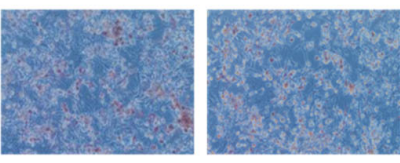

A. senescens

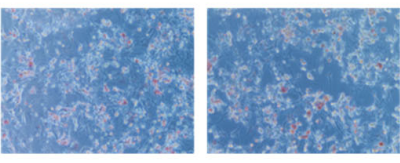

A. sacculiferum

Figure 3. Cont. 


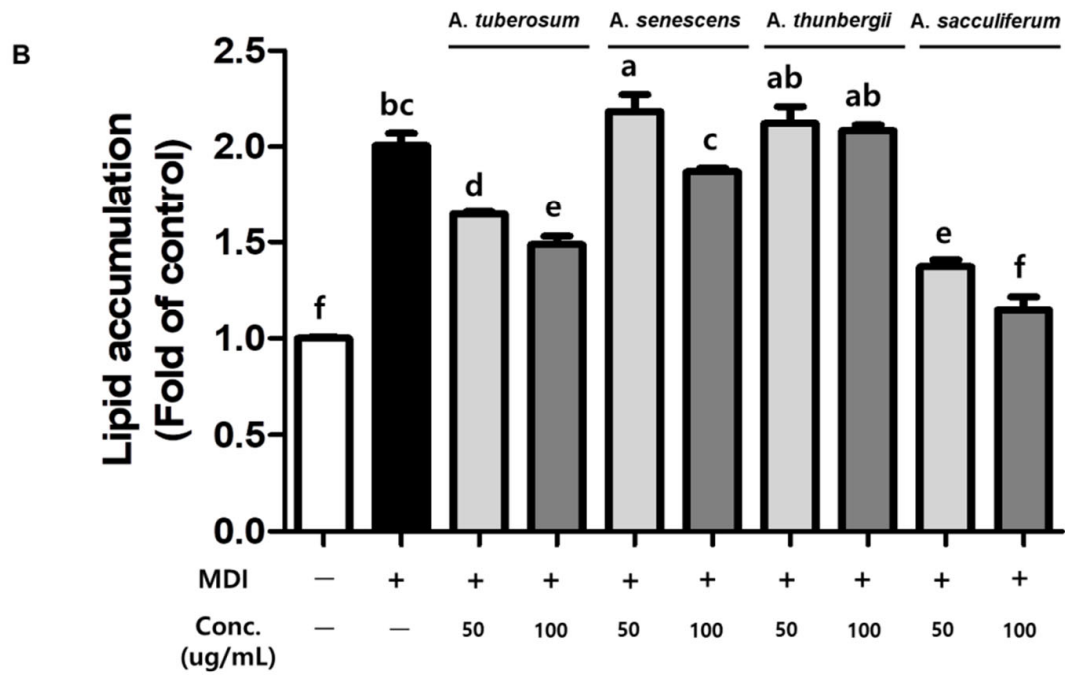

Figure 3. Inhibition of lipid accumulation by Allium spp. extracts, as analyzed by microscopy (A) and quantifications (B). Differentiated 3T3-L1 cells were treated every 2 days with extracts (50 and $100 \mu \mathrm{g} / \mathrm{mL})$ for 8 days in adipocyte-induction media. All values are means $\pm \operatorname{SD}(n=3)$. Values with different superscript letters indicate a statistically significant difference determined by Duncan's test $(p<0.05)$. MDI, media of differentiation; Conc., concentration.

\subsection{Profiling of Phenolics in Allium Spp.}

Chromatographic techniques are necessary for identifying bioactive compounds [34]. Thus, we performed a high performance liquid chromatography (HPLC) analysis to determine the phenolics present in Allium spp. Homogenetic acids were detected in all Allium spp. Additionally, caffeic acid and ferulic acid were detected in A. tuberosum and A. sacculiferum. Veratric acid and quercetin were detected in A. senescens, and ferulic acid, veratric acid, and quercetin were detected in A. thunbergii (Figure 4).

A quantitative analysis using each calibration curve showed that homogentisic acid was highest in $A$. senescens ( $75.7 \pm 1.6 \mu \mathrm{g} / \mathrm{g}$ d.b. extract), followed by that in A. sacculiferum $(63.0 \pm 0.5 \mu \mathrm{g} / \mathrm{g}$ d.b. extract), A. tuberosum ( $50.8 \pm 0.7 \mu \mathrm{g} / \mathrm{g}$ d.b. extract), and $A$. thunbergii $(47.8 \pm 0.5 \mu \mathrm{g} / \mathrm{g}$ d.b. extract) (Table 4). Caffeic acid was only detected in A. thunbergii $(3.9 \pm 0.1 \mu \mathrm{g} / \mathrm{g}$ d.b. extract) and A. sacculiferum $(3.6 \pm 0.1 \mu \mathrm{g} / \mathrm{g}$ d.b. extract). Ferulic acid was highest in $A$. tuberosum $(15.9 \pm 0.1 \mu \mathrm{g} / \mathrm{g}$ d.b. extract), with $A$. thunbergii $(0.6 \pm 0.2 \mu \mathrm{g} / \mathrm{g}$ d.b. extract $)$ and $A$. sacculiferum $(0.3 \pm 0.1 \mu \mathrm{g} / \mathrm{g}$ d.b. extract) having smaller amounts. Veratric acid and quercetin were only detected in $A$. senescens ( $58.9 \pm 1.3$ and $53.8 \pm 0.6 \mu \mathrm{g} / \mathrm{g}$ d.b. extract) and $A$. thunbergii $(54.4 \pm 1.0$ and $44.0 \pm 1.0 \mu \mathrm{g} / \mathrm{g}$ d.b. extract $)$

Based on our results, a correlation analysis was performed between biological activities and phenolics (Table 5). The lipid accumulation correlated with TP $(-0.826)$, DPPH $(0.867)$, ABTS (0.784), and caffeic acid (-0.889). These results show that Allium spp. have a significant correlation with the antioxidant activity of caffeic acid, which inhibits lipid accumulation. 


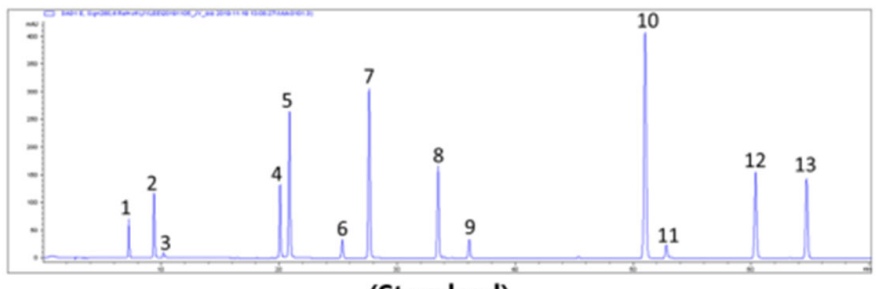

(Standard)

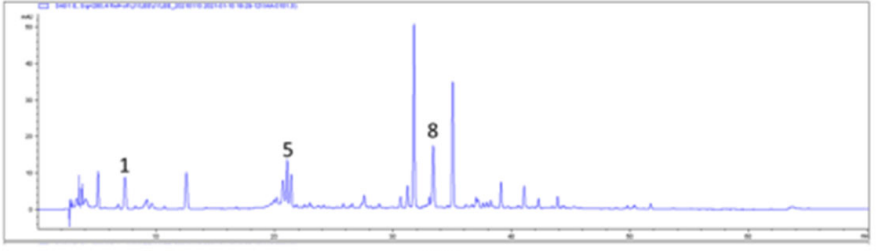

(A)

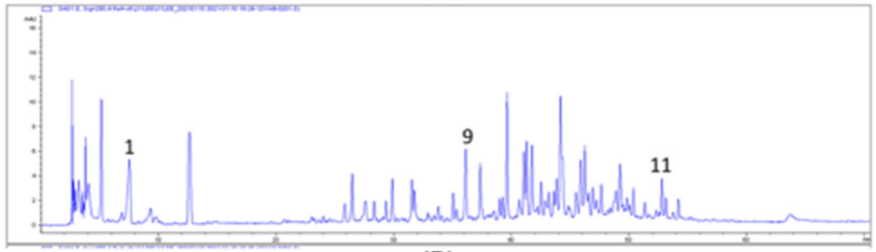

(B)

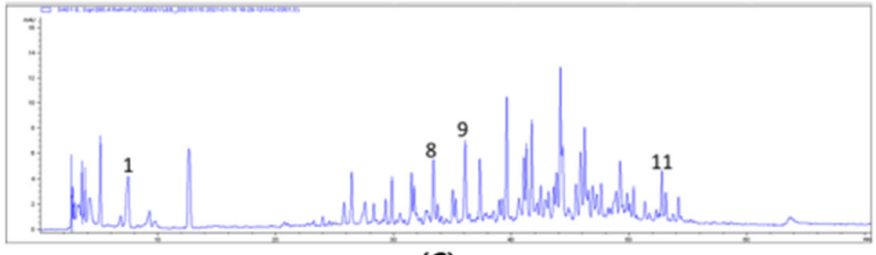

(C)

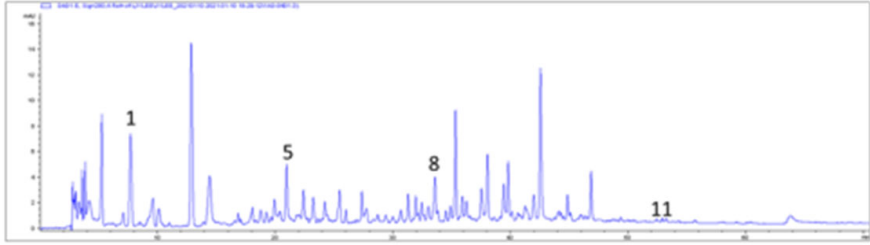

(D)

Figure 4. Chromatogram of phenolic compounds present in water extract of Allium spp., as analyzed by HPLC. Peak identification: 1. homogentisic acid, 2. Protocatechinic acid, 3. Gentisic acid, 4. Chlorogenic acid, 5. Caffeic acid, 6. Propionic acid, 7. Coumaric acid, 8. Ferulic acid, 9. Veratric acid, 10. Cinnamic acid, 11. Quercetin, 12. Naringenin, and 13. Hesperiin. Chromatogram of A. tuberosum (A), A. senescens (B), A. thunbergii (C) and A. sacculiferum (D).

Table 4. Quantitative analysis of phenolic compounds in Allium spp. water extracts.

\begin{tabular}{ccccc}
\hline Phenolics & A. tuberosum & A. senescens & A. thunbergii $^{\text {A. sacculiferum }}$ & A. \\
\hline Homogentic acid & $50.8 \pm 0.7^{\mathrm{c}}$ & $75.7 \pm 1.6^{\mathrm{a}}$ & $47.8^{\mathrm{a}} \pm 0.5^{\mathrm{d}}$ & $63.0 \pm 0.5^{\mathrm{b}}$ \\
Caffeic acid & $3.9 \pm 0.1^{\mathrm{a}}$ & N.D. $^{1}$ & N.D. & $3.6 \pm 0.1^{\mathrm{b}}$ \\
Ferulic acid & $15.9 \pm 0.1^{\mathrm{a}}$ & N.D. & $0.6 \pm 0.2^{\mathrm{b}}$ & $0.3 \pm 0.1^{\mathrm{c}}$ \\
Veratric acid & N.D. & $58.9 \pm 1.3^{\mathrm{a}}$ & $54.4 \pm 1.0^{\mathrm{b}}$ & N.D. \\
Quercetin & N.D. & $53.8 \pm 0.6^{\mathrm{a}}$ & $44.0 \pm 1.0^{\mathrm{b}}$ & N.D. \\
\hline
\end{tabular}

${ }^{1}$ Values are indicated as content ( $\mu \mathrm{g} / \mathrm{g}$ d.b. extract). N.D.; not detected. Values are shown as mean $\pm \mathrm{SD}(n=3)$ Values with different superscript letters in the same row indicate statistically significant differences as determined by Duncan's test $(p<0.05)$. 
Table 5. Correlation analysis with biological activity and phenolics in Allium spp. extracts.

\begin{tabular}{|c|c|c|c|c|c|c|c|}
\hline Factors & $\mathrm{TP}^{1}$ & Homogentic Acid & Caffeic Acid & Ferulic Acid & $\mathrm{DPPH}^{2}$ & ABTS $^{3}$ & Lipid Accumulation \\
\hline $\mathrm{TP}$ & & -0.373 & 0.932 & 0.464 & $-0.796^{* *}$ & -0.439 & $-0.826^{* * *}$ \\
\hline Homogentic acid & & & -0.238 & -0.474 & -0.024 & $-0.587^{*}$ & -0.120 \\
\hline Caffeic acid & & & & $0.618 *$ & -0.931 & $-0.633 *$ & $-0.889^{* * *}$ \\
\hline Ferulic acid & & & & & $-0.595 *$ & -0.231 & -0.248 \\
\hline DPPH & & & & & & $0.811^{* *}$ & $0.867^{* * *}$ \\
\hline ABTS & & & & & & & $0.784^{* *}$ \\
\hline Lipid accumulation & & & & & & & \\
\hline
\end{tabular}

${ }^{1}$ Total phenolic acid (mg GA/g extract). ${ }^{2,3}$ Values are indicated as $\mathrm{IC}_{50}$ values $(\mu \mathrm{g} / \mathrm{mL})$. Values are shown as mean $\pm \mathrm{SD}(n=3)$. Statistically significant differences determined using Pearson's correlation coefficient $\left({ }^{*} p<0.05,{ }^{* *} p<0.01\right.$, and $\left.{ }^{* * *} p<0.001\right)$.

\section{Discussion}

A. tuberosum is widely consumed as a traditional ingredient in Korea and has been used as an herbal medicine for a long time [12]. However, the biological activity of leeks grown in Korea is only known for only few of the Allium spp. There have been many studies analyzing the functional activity of Allium spp. methanol extracts in preventing obesity $[16,17,19]$. However, methanol extracts cannot be used as food. We selected three types of Allium spp. with anti-obesity effects, and A. thunbergii, which is often used interchangeably with $A$. sacculiferum although it was found to be an independent spp. In a recent study [35]. In this study, we investigated the growth characteristics, secondary metabolites, and beneficial effects of Allium spp. In Korea for use as food, and the correlation between them.

The antioxidant effect of plants is known to be beneficial not only for plants but also for humans. For example, various phenolic substances have been reported to have an excellent free radical scavenging ability. Free radicals in vivo affect aging and disease in living tissue. Plant phenolic compounds are known to exhibit physiologically active functions by binding phenolic hydroxyl groups to macromolecules, such as enzymes [36]. TP is known to have a high antioxidant activity, which is because the phenolic hydroxyl group $(\mathrm{OH})$ of the compound binds to proteins and polymers. In general, it has been reported that as the content of TP increases, physiological activities such as antioxidant activity increase [37]. DPPH and ABTS radicals are relatively stable free radicals and are reduced by sulfur-containing amino acids such as cysteine, GSH, ascorbate, and butylated hydroxyanisole. Accordingly, DPPH and ABTS are widely used to analyze the in vitro antioxidant activity of various extracts [38]. On comparing the antioxidant effect of all Allium spp., A. sacculiferum was identified to have the highest radical scavenging effect and TP content.

Adipogenesis is similar to the development of obesity in humans, and the excessive differentiation of 3T3-L1 cells into pre-adipocytes can induce obesity; therefore, these cells have been widely used in studies that assess the characteristics of adipogenesis and obesity [39]. A correlation between antioxidants and adipogenesis has been reported to promote the conversion of pre-adipocytes to mature adipocytes [24]. Thus, to investigate the inhibitory effect of $A$. tuberosum and A. sacculiferum extracts, which were found to have high antioxidant activity, ORO staining was performed. They had an inhibitory effect on the formation of lipid droplets. Therefore, A. tuberosum and A. sacculiferum extracts, which have been confirmed to have antioxidant activity, can be utilized for their anti-adipogenic effects.

According to a number of recent studies, plant-derived phenolic compounds inhibit adipogenesis [40]. Phenolic profiling was performed utilizing an HPLC analysis to determine the component responsible for the inhibitory action of Allium spp. In our study, caffeic acid was detected in A. tuberosum and A. sacculiferum. Caffeic acid has been reported to be an anti-obesity agent [41]. Using our data, an analysis was conducted to determine the correlation between phenolics and the biological activities of Allium spp. (Table 5). The 
anti-adipogenic and antioxidant effects of $A$. tuberosum and A. sacculiferum may be due to its caffeic acid content.

Collectively, these results suggest that Allium spp. have potential antioxidant and antiadipogenic effects, which derive from the presence of phenolic compounds, particularly caffeic acid.

\section{Conclusions}

Among Allium spp., A. tuberosum and A. sacculiferum have the antioxidant potential of scavenging free radicals and also inhibit adipogenesis in 3T3-L1 cells by decreasing lipid accumulation. The properties of these species were found to be correlated with their phenolic content, specifically caffeic acid. Consequently, various metabolites and phenolic compounds were found to differ according to Allium spp., thus showing differences among the Allium spp., with respect to their beneficial biological effects.

Author Contributions: Conceptualization, K.H.S. and H.D.K.; methodology, J.Y.L., E.Y.L. and Y.-J.J.; data curation K.H.S., E.Y.L., M.H.K. and H.-A.S.; resources, J.Y.L., K.H.S. and Y.J.L.; writing—original draft preparation, J.Y.L., K.H.S. and E.Y.L.; writing-review and editing, K.H.S. and H.D.K.; funding acquisition, M.H.K. and H.D.K. All authors have read and agreed to the published version of the manuscript.

Funding: This work was carried out with the support of the "Cooperative Research Program for Agriculture Science and Technology Development (Project No. PJ01361601)" and the RDA Fellowship Program of the National Institute of Horticultural and Herbal Science, Rural Development Administration, Korea.

Institutional Review Board Statement: Not applicable.

Informed Consent Statement: Not applicable.

Conflicts of Interest: The authors declare no conflict of interest. The funding sponsors had no role in the design of the study, collection, analyses, or interpretation of the data, writing of the manuscript, or the decision to publish the results.

\section{References}

1. Dandona, P.; Ghanim, H.; Chaudhuri, A.; Dhindsa, S.; Kim, S.S. Macronutrient intake induces oxidative and inflammatory stress: Potential relevance to atherosclerosis and insulin resistance. Exp. Mol. Med. 2010, 42, 245-253. [CrossRef] [PubMed]

2. Betteridge, D.J. What is oxidative stress? Metabolism 2000, 49, 3-8. [CrossRef]

3. Sies, H.; Berndt, C.; Jones, D.P. Oxidative stress. Annu. Rev. Biochem. 2017, 86, 715-748. [CrossRef] [PubMed]

4. De Villiers, D.; Potgieter, M.; Ambele, M.A.; Adam, L.; Durandt, C.; Pepper, M.S. The role of reactive oxygen species in adipogenic differentiation. In Genome Editing; Springer: Cham, Switzerland, 2017; Volume 1083, pp. 125-144.

5. Haida, Z.; Hakiman, M. A comprehensive review on the determination of enzymatic assay and nonenzymatic antioxidant activities. Food Sci. Nutr. 2019, 7, 1555-1563. [CrossRef]

6. Wang, Y.W.; Jones, P.J. Conjugated linoleic acid and obesity control: Efficacy and mechanisms. Int. J. Obes. 2004, 28, 941-955. [CrossRef]

7. Ahmad, P.; Jaleel, C.A.; Salem, M.A.; Nabi, G.; Sharma, S. Roles of enzymatic and nonenzymatic antioxidants in plants during abiotic stress. Crit. Rev. Biotechnol. 2010, 30, 161-175. [CrossRef]

8. Jain, C.; Khatana, S.; Vijayvergia, R. Bioactivity of secondary metabolites of various plants: A review. Int. J. Pharm. Sci. Res. 2019, 10, 494-498.

9. Lattanzio, V.; Kroon, P.A.; Quideau, S.; Treutter, D. Plant phenolics-Secondary metabolites with diverse functions. Recent Adv. Polyphen. Res. 2008, 1, 1-35.

10. Rice-Evans, C.; Miller, N.; Paganga, G. Antioxidant properties of phenolic compounds. Trends Plant Sci. 1997, 2, 152-159. [CrossRef]

11. Chrząszcz, M.; Krzemińska, B.; Celiński, R.; Szewczyk, K. Phenolic Composition and Antioxidant Activity of Plants Belonging to the Cephalaria (Caprifoliaceae) Genus. Plants 2021, 10, 952. [CrossRef] [PubMed]

12. Choi, H.J.; Oh, B.U. A partial revision of Allium (Amaryllidaceae) in Korea and north-eastern China. Bot. J. Linn. Soc. 2011, 167, 153-211. [CrossRef]

13. Lee, J.H.; Yang, H.S.; Park, K.W.; Kim, J.Y.; Lee, M.K.; Jeong, I.Y.; Seo, K.I. Mechanisms of thiosulfinates from Allium tuberosum L.-induced apoptosis in HT-29 human colon cancer cells. Toxicol. Lett. 2009, 188, 142-147. [CrossRef]

14. Wang, Y.; Wang, C.; Gu, Y.; Wang, P.; Song, W.; Ma, J.; Yang, X. The variability of bacterial communities in both the endosphere and ectosphere of different niches in Chinese chives (Allium tuberosum). PLoS ONE 2020, 15, e0227671. [CrossRef] [PubMed] 
15. Tang, X.; Olatunji, O.J.; Zhou, Y.; Hou, X. Allium tuberosum: Antidiabetic and hepatoprotective activities. Food Res. Int. 2017, 102, 681-689. [CrossRef]

16. Park, H.S.; Choi, E.J.; Lee, J.H.; Kim, G.H. Evaluation of Allium vegetables for anti-adipogenic, anti-cancer, and anti-inflammatory activities in vitro. J. Life Sci. 2013, 5, 127-132. [CrossRef]

17. Choi, H.Y.; Kim, G.H. Inhibitory effects of Allium senescens L. methanol extracts on reactive oxygen species production and lipid accumulation during differentiation in 3T3-L1 cells. Korean J. Food Sci. Technol. 2014, 46, 498-504. [CrossRef]

18. Kim, J.; Lee, D.H.; Badamtsetseg, B.; Lee, S.; Kim, S. Anti-Proliferative Effect of Allium senescens L. Extr. Hum. T-Cell Acute Lymphocytic Leuk. Cells. Mol. 2021, 26, 35.

19. Choi, H.Y.; Kim, G.H. Inhibitory effects of Allium sacculiferum Max. methanol extracts on ROS production and lipid accumulation during differentiation of 3T3-L1 cells. J. Korean Soc. Food Sci. Nutr. 2014, 43, 822-828. [CrossRef]

20. Choi, H.J.; Jang, C.G.; Ko, S.C.; Oh, B.U. A taxonomic review of Korean Allium (Alliaceae). Korean J. Plant Taxon. 2004, 34, 119-152. [CrossRef]

21. Gulcin, İ. Antioxidants and antioxidant methods: An updated overview. Arch. Toxicol. 2020, 94, 651-715. [CrossRef] [PubMed]

22. Riss, T.L.; Moravec, R.A.; Niles, A.L.; Duellman, S.; Benink, H.A.; Worzella, T.J.; Minor, L. Cell Viability Assays. Assay Guidanced Manual; Eli Lilly \& Company and the National Center for Advancing Translational Sciences: Bethesda, MD, USA, 2016 ; pp. 1-25.

23. Lee, J.Y.; Park, J.Y.; Kim, H.D.; Lee, S.E.; Lee, J.H.; Lee, Y.; Seo, K.H. Anti-oxidant and anti-adipocyte differentiation of Aster glehni and Aster yomena. J. Nutr. Health 2019, 52, 250-257. [CrossRef]

24. Kinkel, A.D.; Fernyhough, M.E.; Helterline, D.L.; Vierck, J.L.; Oberg, K.S.; Vance, T.J.; Dodson, M.V. Oil red-O stains nonadipogenic cells: A precautionary note. Cytotechnology 2004, 46, 49-56. [CrossRef]

25. Nazlić, M.; Kremer, D.; Grubešić, R.J.; Soldo, B.; Vuko, E.; Stabentheiner, E.; Dunkić, V. Endemic Veronica saturejoides Vis. ssp. saturejoides-Chemical composition and antioxidant activity of free volatile compounds. Plants 2020, 9, 1646. [CrossRef] [PubMed]

26. Tanruean, K.; Poolprasert, P.; Suwannarach, N.; Kumla, J.; Lumyong, S. Phytochemical Analysis and Evaluation of Antioxidant and Biological Activities of Extracts from Three Clauseneae Plants in Northern Thailand. Plants 2021, 10, 117. [CrossRef] [PubMed]

27. Bärlocher, F.; Graça, M.A. Total Phenolics. Methods to Study Litter Decomposition; Springer: Berlin/Heidelberg, Germany, 2020; pp. 157-161.

28. Lee, J.Y.; Park, J.Y.; Seo, H.T.; Seong, H.A.; Ji, Y.J.; Lee, S.E.; Kim, H.D. Samnamul (Shoots of Aruncus dioicus) Inhibit Adipogenesis by Downregulating Adipocyte-Specific Transcription Factors in 3T3-L1 Adipocytes. Processes 2020, 8, 1576. [CrossRef]

29. Malich, G.; Markovic, B.; Winder, C. The sensitivity and specificity of the MTS tetrazolium assay for detecting the in vitro cytotoxicity of 20 chemicals using human cell lines. Toxicology 1997, 124, 179-192. [CrossRef]

30. Ouyang, L.; Yao, R.; Chen, X.; Na, J.; Sun, W. 3D printing of HEK 293FT cell-laden hydrogel into macroporous constructs with high cell viability and normal biological functions. Biofabrication 2015, 7, 015010. [CrossRef] [PubMed]

31. Gregoire, F.M. Adipocyte differentiation: From fibroblast to endocrine cell. Exp. Biol. Med. 2001, 226, 997-1002. [CrossRef] [PubMed]

32. Ilavenil, S.; Arasu, M.V.; Lee, J.C.; Kim, D.H.; Roh, S.G.; Park, H.S.; Choi, K.C. Trigonelline attenuates the adipocyte differentiation and lipid accumulation in 3T3-L1 cells. Phytomedicine 2014, 21, 758-765. [CrossRef] [PubMed]

33. Granato, D.; Shahidi, F.; Wrolstad, R.; Kilmartin, P.; Melton, L.D.; Hidalgo, F.J.; Finglas, P. Antioxidant activity, total phenolics and flavonoids contents: Should we ban in vitro screening methods? Food Chem. 2018, 264, 471-475. [CrossRef]

34. Choi, H.J.; Oh, B.U. Taxonomy of the Allium sect. Sacculiferum in Korea: With a special reference to the morphology. Korean J. Plant Taxon. 2003, 33, 339-357. [CrossRef]

35. Achakzai, A.K.K.; Achakzai, P.; Masood, A.; Kayani, S.A.; Tareen, R.B. Response of plant parts and age on the distribution of secondary metabolites on plants found in Quetta. Pak. J. Bot 2009, 41, 2129-2135.

36. Pandey, K.B.; Rizvi, S.I. Plant polyphenols as dietary antioxidants in human health and disease. Oxidative Med. Cell. Longev. 2009, 2, 270-278. [CrossRef]

37. Kwak, C.S.; Kim, M.J.; Kim, S.G.; Park, S.; Kim, I.G.; Kang, H.S. Antioxidant and antiobesity activities of oral treatment with ethanol extract from sprout of evening primrose (Oenothera laciniata) in high fat diet-induced obese mice. J. Nutr. Health 2019, 52, 529-539. [CrossRef]

38. Gülçin, İ.; Berashvili, D.; Gepdiremen, A. Antiradical and antioxidant activity of total anthocyanins from Perilla pankinensis decne. J. Ethnopharmacol. 2005, 101, 287-293. [CrossRef] [PubMed]

39. Poudel, B.; Lim, S.W.; Ki, H.H.; Nepali, S.; Lee, Y.M.; Kim, D.K. Dioscin inhibits adipogenesis through the AMPK/MAPK pathway in 3T3-L1 cells and modulates fat accumulation in obese mice. Int. J. Mol. Med. 2014, 34, 1401-1408. [CrossRef] [PubMed]

40. Hsu, C.L.; Yen, G.C. Effects of flavonoids and phenolic acids on the inhibition of adipogenesis in 3T3-L1 adipocytes. J. Agric. Food Chem. 2007, 55, 8404-8410. [CrossRef] [PubMed]

41. Juman, S.; Yasui, N.; Okuda, H.; Ueda, A.; Negishi, H.; Miki, T.; Ikeda, K. Caffeic acid phenethyl ester inhibits differentiation to adipocytes in 3T3-L1 mouse fibroblasts. Biol. Pharm. Bull. 2010, 33, 1484-1488. [CrossRef] [PubMed] 